\title{
How drying methods can influence the characteristics of mucilage obtained from chia seed and psyllium husk
}

\section{Jéssica Loraine Duenha Antigo ${ }^{1}\left([)\right.$ Rita de Cássia Bergamasco ${ }^{2}\left([)\right.$ Grasiele Scaramal Madrona $^{2 *}(\mathbb{C})$}

${ }^{1}$ Pós-graduação em Ciência de Alimentos, Universidade Estadual de Maringá (UEM), Maringá, PR, Brasil.

${ }^{2}$ Departamento de Engenharia de Alimentos, Universidade Estadual de Maringá (UEM), 87900-062, Maringá, PR, Brasil. E-mail: gsmadrona@uem.br. "Corresponding author.

ABSTRACT: The influence of drying methods (oven drying at $50{ }^{\circ} \mathrm{C}$, and freeze drying) on the centesimal composition, functional characteristics and rheological properties of mucilage obtained from chia seed and psyllium husk were investigated. Results showed that high temperature of oven drying reduced fiber content, solubility, emulsion activity and emulsion stability of mucilage. All samples showed pseudo plastic behavior, with the best result produced by Heschel-Bulkley and Power Law models of chia and psyllium mucilage, respectively. These results will be helpful in selecting suitable drying methods depending on the functional and rheological properties desired of the chia and psyllium mucilage in a food product.

Key words: freeze drying, oven drying; viscosity, solubility, emulsion stability.

Como os métodos de secagem podem influenciar as características da mucilagem obtida de sementes de chia e casca de psyllium

RESUMO: Este estudo teve como objetivo avaliar a influência dos métodos de secagem (secagem em estufa a $50{ }^{\circ} \mathrm{C}$ e liofilização) sobre a composição centesimal, características funcionais e propriedades reológicas da mucilagem obtida a partir de sementes de chia e casca de psyllium. Os resultados mostraram que a alta temperatura de secagem em estufa reduziu o teor de fibras, a solubilidade, a atividade da emulsão e a estabilidade da emulsão das mucilagens. Todas as amostras apresentaram comportamento pseudoplástico, com o melhor ajuste produzido pelos modelos Heschel-Bulkley e Power Law das mucilagens de chia e psyllium, respectivamente. Estes resultados serão úteis na seleção do método de secagem adequado, dependendo das propriedades funcionais e reológicas desejadas das mucilagens de chia e psyllium. Palavras-chave: secagem por liofilização, secagem em estufa, viscosidade, solubilidade e estabilidade de emulsão.

\section{INTRODUCTION}

Some plants may produce complex polysaccharides which are commercially known as plant gums. There are several studies on plant gums that have resulted in the identification of valuable natural sources of complex carbohydrate polymers that promote desired quality, stability, texture and appearance in food products (MIRHOSSEINI \& AMID, 2012). Recently, there has been increased interest in the physical and functional properties of plant gum exudates and seed gums from new sources, for example chia (Salvia hispanica L.) and psyllium (Plantago ovata).

Chia is a plant native to Mexico, and has been increasingly important for human health and nutrition because of its high content of polyunsaturated fatty acids source of omega 3, fibers and proteins (MARTÍNEZ-CRUZ \& PAREDES-LOPES, 2014). When chia seeds are dipped in water, the cuticles break down, and the cell content, a transparent mucilaginous gel composed essentially of soluble fibers, gradually exudes (CAPITANI et al., 2013a). This mucilage has been used in various traditional food products including ice cream, breads and cakes (CAMPOS et al., 2016; FERNANDES et al., 2017).

Psyllium husks and seeds of the genus Plantago are an excellent source of both soluble and insoluble fibers (YU et al., 2001). Soluble fiber promotes a favorable effect on glucose and insulin metabolism if administered in sufficient amounts 
(RUDKOWSKA, 2012). In contact with water, psyllium husk forms a gel known as psyllium gum that has high viscosity (AL-ASSAF et al., 2003). The largest application of psyllium mucilage is in the pharmaceutical industry, but there are some studies in food processing, such as cookie fortification and starch-based edible films (RAYMUNDO et al., 2014; KRYSTYJAN, et al., 2017).

Mucilage from chia seed and psyllium husk has been extensively studied by our research group as emulsifiers, stabilizers and thickeners in food. However, fresh mucilage is susceptible to microbial attack due to its high water activity $(>0.8)$ and composition, reducing its shelf life to a few days (2-3) at a temperature of $25^{\circ} \mathrm{C}$. Therefore, it is necessary to extend mucilage shelf life by multiple preservation process (LEÓN-MARTINEZ et al., 2011). In addition, mucilage utilization depends on its unique functional properties such as solubility, emulsion stability, rheological properties. These functional properties are sensitive to preparation methods and could be altered to great extent by the drying process (WANG et al., 2010).

Among different drying methods reported in literature, we highlight oven drying and freeze drying, which were the methods chosen to be evaluated in this research, based on preliminary experiments. Thus, the objective of this research was to evaluate the influence of drying methods on activity and emulsion stability, solubility and rheological properties of mucilage extracted from chia seed and psyllium husk.

\section{MATERIALS AND METHODS}

As raw material, the seeds of chia (Salvia hispanica L) and psyllium husks (Plantago ovata), both obtained from local commerce in the city of Maringa - Parana, Brazil, were used.

For the extraction of chia mucilage, the methodology described by CAMPOS et al. (2016), was used with modifications. Chia mucilage was extracted from seeds using distilled water, in a ratio of 1:30 (seeds: water). Temperature of the water bath during extraction was maintained at $50{ }^{\circ} \mathrm{C}$, with stirring at $1500 \mathrm{rpm}$, for 2 hours. The aqueous suspension was separated from the seed using a cotton cloth.

For the extraction of psyllium husk mucilage, the methodology described by Guo et al. (2008), with modifications, was used. Psyllium husk mucilage was extracted using distilled water in a ratio of 1: 100 (husk: water). Temperature of the water bath during extraction was maintained at $80^{\circ} \mathrm{C}$ with stirring for 1.2 hours. Aqueous suspension was separated from the husk using a cotton cloth.

Two drying conditions were tested, the first oven drying with forced air circulation at $50{ }^{\circ} \mathrm{C}$ for 24 hours, and constant air velocity $(1 \mathrm{~m} / \mathrm{s})$. In the second samples were frozen for 48 hours at $-18{ }^{\circ} \mathrm{C}$ then submitted a freeze dryer (Liobras, model L108) for 96 hours, at $-50{ }^{\circ} \mathrm{C}$ and $30 \mathrm{mmHg}$ of pressure, until the mucilage film was obtained. The samples CO (chia mucilage dried in oven), CF (chia mucilage dried in freeze dryer), PO (psyllium mucilage dried in oven) and PF (psyllium mucilage dried in freeze dryer) were obtained. The extractions yields were calculated using equation 1 .

process yield $(\%)=\frac{d r y \text { mucilage weight }}{\text { seed } / \text { husk weight }} .100$

Mucilage centesimal composition, emulsifying activity (EA) and emulsion stability (ES)

To determine moisture and ash content of chia and psyllium mucilage, the methodology described by the Association of Official Analytical Chemists (AOAC, 2000) was followed. The crude protein content was determined by the classical Kjeldahl method, with a factor of 6.25 (AOAC, 2000). Determination of total dietary fiber content was performed based on the AOAC 985.29 (enzymatic-gravimetric) method, modified by Prosky et al. (1988). For the analysis of total fat, the AOAC 991.36 method was used. Carbohydrate content was estimated as nitrogen-free extract (NFE) by difference using equation 2 :

$\mathrm{NFE}=100-($ fat + protein + crude fiber + ash $)$

To test emulsifying activity and emulsion stability, the methodology described by CHAU et al. (1997) was used, with modifications. For emulsifying activity, a $1 \%$ mucilage aqueous solution was prepared and homogenized on a mechanical stirrer (Fisatom 7BD), for 2 minutes at $1000 \mathrm{rpm}$. A volume of $50 \mathrm{~mL}$ of canola oil was added to the suspension, and homogenized at $5000 \mathrm{rpm}$ for 5 minutes. The emulsion was then centrifuged in a centrifuge (Gemmy Industrial Corp.) at $503.1 \mathrm{x} \mathrm{g}$ for 20 minutes. The volume of the emulsified layer was measured and expressed as a percentage of emulsifying activity.

For emulsion stability, the emulsion obtained in the emulsifying activity test was heated at $80{ }^{\circ} \mathrm{C}$ for 30 minutes in a water bath, then cooled to room temperature $\left(25^{\circ} \mathrm{C}\right)$, and centrifuged at 503,1 $\mathrm{x} g$ for $20 \mathrm{~min}$. The volume of the emulsified layer was measured and expressed as a percentage of emulsion stability. 


\section{Solubility}

The solubility of crude mucilage was determined using the method described by BETANCURANCONA et al. (2003). A volume of $40 \mathrm{~mL}$ of mucilage aqueous solution $(1 \%)$ was placed for $30 \mathrm{~min}$, in water bath with stirring, at temperatures of $25,30,50,60,80$ ${ }^{\circ} \mathrm{C}$. The solution was then centrifuged at $2120 \mathrm{x}$ g for 15 minutes. A $10 \mathrm{~mL}$ aliquot of the supernatant was added to a petri dish and dried in an oven with air circulation at $120^{\circ} \mathrm{C}$ for 4 hours.

Sample solubility was calculated using equation 3 .

$$
\text { solubility }(\% w / w)=\frac{\text { dry weight of aliquot taken }}{\text { total sample weight }} .100
$$

\section{Rheological properties}

To evaluate sample rheological properties, the methodology described by Li \& Chang (1997) was used. A $1 \%$ mucilage aqueous solution, which was stirred by mechanical stirrer for 2 hours, was analyzed on a Brookfield viscometer model DV-III (Brookfield Engineering Lab., Stoughton, MA) with spindle 27, intervals of rotational speed of 3 to $78 \mathrm{rpm}$ at $25{ }^{\circ} \mathrm{C}$, and 30 second viscosity reading intervals. The viscosity data was expressed in Pa.s.

Different models of flow (Power law, Bingham, Herschel-Bulkley, Casson) (SALEHI \& KASHANINEJAD, 2014; SALEHI \& KASHANINEJAD, 2015) were used to adjust the mucilage shear stress experimental data.

The power law model is expressed by:

$\tau=k \cdot \gamma^{n_{p}}$

Where $\tau$ is the shear stress $(\mathrm{Pa}), \mathrm{k}$ is the flow consistency index $\left(\mathrm{Pa} . \mathrm{s}^{\mathrm{n}}\right), \gamma$ is the shear rate $\left(\mathrm{s}^{-1}\right)$ and $n$ the flow behavior index.

The Bingham model is expressed by:

$\tau=\tau_{0 B}+\eta_{B} \cdot \gamma$

Where $\eta_{B}$ is the apparent viscosity of Bingham (Pa.s) and $\tau_{0 \mathrm{~B}}$ is the Bingham yield stress (Pa).

The Herschel-Bulkley model is expressed by:

$$
\tau=\tau_{0 H}+k_{H} \cdot \gamma^{n_{H}}
$$

Where $k_{H}$ is the consistency coefficient $\left(\mathrm{Pa} . \mathrm{S}^{\mathrm{n}}\right), \tau_{0 \mathrm{H}}$ is the yield stress $(\mathrm{Pa})$ and $n_{H}$ is the flow behavior index for the Herschel-Bulkley model.

The Casson model is expressed by:

$\tau^{0.5}=\tau_{0 C}^{0.5}+\eta_{C} \cdot \gamma^{0.5}$

Where $\eta_{C}$ is the plastic viscosity (Pa.s) and $\tau_{0 C}$ is the yield stress $(\mathrm{Pa})$ for the Casson model.

\section{Statistical analysis}

Data were expressed as average \pm standard deviation and submitted to analysis of variance
(ANOVA). We adopted the significance level of $5 \%$ for rejection of the null hypothesis $(\mathrm{P}<0.05)$ for the Tukey test, and correlation analysis and data modeling, including standard error (SE), was performed with nonlinear analysis functions using the software STATISTICA ${ }^{\circledR}$ version 8.0 (StatSoft, Inc., Tulsa, OK, USA).

\section{RESULTS AND DISCUSSION}

Yield is directly influenced by the content of polysaccharides present in husks or seeds, while psyllium husks have a content of $84.98 \%$ (GUO et al., 2009), chia seeds have only $18.70 \%$ polysaccharides (BUSHWAY et al., 1981). Mucilage from chia seed dried in oven and freezer dryer showed an extraction yield of $4.38 \pm 1.06 \%$ and $5.86 \pm 0.29 \%$, respectively; while mucilage from psyllium husk showed an extraction yield of $52.11 \pm 1.65 \%$ and $55.45 \pm 0.38 \%$ for samples dried in oven and freezer dryer, respectively. As expected, samples showed no significant difference in yield regarding drying methods, since yield is related to the method of extraction and separation of mucilage from seeds or husk.

Mucilage centesimal composition, emulsifying activity and emulsion stability

The centesimal composition of chia and psyllium mucilage samples dried in oven and freeze dryer is shown in table 1. Moisture content is a critical parameter that affects shelf life of a product, higher moisture equals greater potential for microorganism proliferation (MIRHOSSEINI et al., 2013). In this research, the moisture content was significantly influenced by the drying conditions. It is possible to observe that chia mucilage dried in oven had higher moisture content than that dried by freeze drying. However, opposite behavior was observed with psyllium samples, where the sample dried by freeze drying presented higher moisture content. This could be due to different drying conditions, i.e., time and temperature.

Generally, the drying process can reduce mucilage average molecular weight, and freeze drying has a less destructive effect on chemical and molecular structure of gums compared to other drying techniques, given the minimal thermal degradation afforded by freeze drying (MIRHOSSEINI et al. 2013). This fact was observed on the crude protein content of psyllium mucilage that was significantly reduced in the oven dried samples. However, this behavior was not observed for chia mucilage and may be due to the way the protein is bound to the 
Table 1 - Centesimal composition ( $\mathrm{g} / 100 \mathrm{~g}$ ) of chia and psyllium mucilage samples by different drying methods.

\begin{tabular}{|c|c|c|c|c|c|c|}
\hline & Moisture & Ash & Protein & Crude fiber & Total fat & Carbohydrate \\
\hline $\mathrm{CO}$ & $12.69^{\mathrm{a}} \pm 0.37$ & $10.88^{a} \pm 0.31$ & $9.38^{a} \pm 0.02$ & $18.27^{b} \pm 0.11$ & $1.98^{\mathrm{a}} \pm 0.06$ & 59.49 \\
\hline $\mathrm{CF}$ & $10.02^{b} \pm 0.72$ & $10.49^{a} \pm 0.96$ & $9.14^{\mathrm{a}} \pm 0.03$ & $22.45^{\mathrm{a}} \pm 0.01$ & $1.90^{\mathrm{a}} \pm 0.00$ & 56.02 \\
\hline \multicolumn{7}{|c|}{ 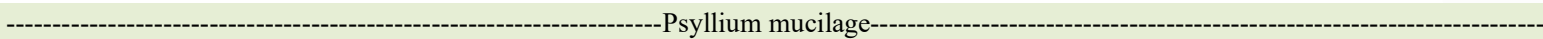 } \\
\hline PO & $11.56^{\mathrm{b}} \pm 0.15$ & $4.05^{\mathrm{a}} \pm 0.11$ & $1.96^{\mathrm{b}} \pm 0.00$ & $4.14^{\mathrm{b}} \pm 0.19$ & $0.55^{\mathrm{b}} \pm 0.02$ & 89.3 \\
\hline $\mathrm{PF}$ & $13.28^{\mathrm{a}} \pm 0.48$ & $2.50^{\mathrm{b}} \pm 0.18$ & $2.43^{\mathrm{a}} \pm 0.01$ & $5.79^{\mathrm{a}} \pm 0.05$ & $1.06^{\mathrm{a}} \pm 0.00$ & 88.22 \\
\hline
\end{tabular}

*Different letters in the same column indicate significant difference ( $<<0.05)$; CO (chia mucilage dried in oven), CF (chia mucilage dried in freeze dryer), PO (psyllium mucilage dried in oven) and PF (psyllium mucilage dried in freeze dryer).

${ }^{* *}$ All measurements are on dry basis, except for moisture and yield.

structure of the polysaccharide, which meant that the drying temperature of $50{ }^{\circ} \mathrm{C}$ did not cause significant damage to the sample.

It is interesting to note that the result of crude protein content for psyllium samples was inversely proportional to ash content, since generally thermal degradation of mucilage structures at high temperatures results in an increase in ash content (MIRHOSSEINI et al., 2013); while for chia samples ash content was not significantly altered by the drying method, even when observed for protein content.

Sample crude fiber content was also affected by the drying method, being higher for the freeze dried samples, probably due to fiber degradation during the dehydration process at high temperature.

Total fat content of chia samples was not significantly altered by the drying method; while for psyllium mucilage, freeze dried sample (PF) showed higher fat content than oven dried sample (PO), this is potentially related to some components that produce volatile compounds due to the heat treatment during drying (NAWAR, 1984).

Emulsifying activity is a molecule's ability to act as an agent that facilitates solubilization or dispersion of two immiscible liquids, and emulsion stability is the ability to maintain an emulsion and its resistance to rupture (ALFREDO et al., 2009). Emulsifying activity and emulsion stability parameters of chia and psyllium mucilage samples are shown in table 2. All mucilage samples showed high emulsifying activity $(>45 \%)$ and high emulsion stability $(>62 \%)$ at low concentrations and room temperature, thus indicating that they could be used in the food industry as a stabilizer and emulsifying agent.

In relation to the different drying methods, freeze dried samples presented higher emulsifying activity and emulsion stability than oven dried samples, probably due to the low temperature used in this type of drying, which preserves chemical and molecular structure (NEP \& CONWAY, 2011) and;

Table 2 - Emulsion activity (EA) and emulsion stability (ES) by different drying methods for mucilage of chia and psyllium.

\begin{tabular}{lcc}
\hline & EA $(\%)$ & ES $(\%)$ \\
\hline$-1-0-10-10$ & $62.39^{\mathrm{b}} \pm 1.40$ \\
CO & $45.43^{\mathrm{b}} \pm 0.72$ & $69.41^{\mathrm{a}} \pm 1.47$ \\
\hline PF & $75.64^{\mathrm{a}} \pm 2.23$ & $85.94^{\mathrm{b}} \pm 1.01$ \\
PF & $76.45^{\mathrm{b}} \pm 1.10$ & $92.53^{\mathrm{a}} \pm 0.75$ \\
\hline
\end{tabular}

*Different letters in the same column differ statistically $(\mathrm{P}<0.05)$; CO (chia mucilage dried in oven), CF (chia mucilage dried in freeze dryer), PO (psyllium mucilage dried in oven) and PF (psyllium mucilage dried in freeze dryer). 
consequently, preserves the emulsifying compounds present in the gums. Another reason is that polysaccharides emulsifying ability is most probably based on a small fraction of surface-active proteins attached to the gum (DICKINSON, 2003). As the oven drying method reduced the crude protein of psyllium mucilage (Table 1), it is suggested that this alteration in the protein content may have affected emulsifying ability of psyllium mucilage.

Considering that all samples have high emulsion stability $(>60 \%$ ), it can be concluded that the two drying methods will be preferred over powders when good emulsion properties are desired.

\section{Solubility}

Solubility is the most reliable criterion to evaluate the behavior of a powder in aqueous solution (MIRHOSSEINI et al., 2013). Figure 1 shows the solubility of chia ( $\mathrm{CO}$ and $\mathrm{CF}$ ) and psyllium (PO and $\mathrm{PF}$ ) mucilage as a function of temperature $\left(25{ }^{\circ} \mathrm{C}\right.$ to $\left.80{ }^{\circ} \mathrm{C}\right)$. For all samples analyzed, an increase in solubility was observed with increasing temperature. This could be explained by the fact that the hydrogen bonds between polysaccharide chains are broken at high temperature, and the $\mathrm{OH}-$ groups are exposed to water, thus increasing solubility (SCIARINI et al., 2009).
Chia mucilage shows good solubility at the range of temperature studied (> $60 \%$ ), indicating promising application in food, as texture modifiers and for stabilizing emulsions or dispersions (TIMILSENA et al., 2016), independently of drying method.

Psyllium mucilage shows poor solubility at room temperature $(<30 \%)$, probably due to its composition, with high content of arabinose, a neutral polysaccharide with low solubility in water (FABRE et al., 2015). According to MIRHOSSEINI et al. (2013), the substitution of arabinose affects the solubility of gums. However, at temperatures above $50{ }^{\circ} \mathrm{C}$, solubility is higher than $60 \%$, showing potential application in processes that involve high temperature.

In relation to the drying methods, freeze dried samples showed higher solubility than oven dried samples. The solubility of natural gums depends on the ratio of soluble to insoluble matters, i.e., a decrease in solubility could be related to an increase in insoluble matter (AMID \& MIRHOSSEINI, 2012). Mirhosseini et al. (2013) observed that Durian seed gum freeze dried showed higher solubility than oven dried samples. The authors suggested that the drying process influences the content of galactose, glucose, arabinose and xylose present in the chemical structure of polysaccharides, and this might be responsible for the significant changes in solubility.

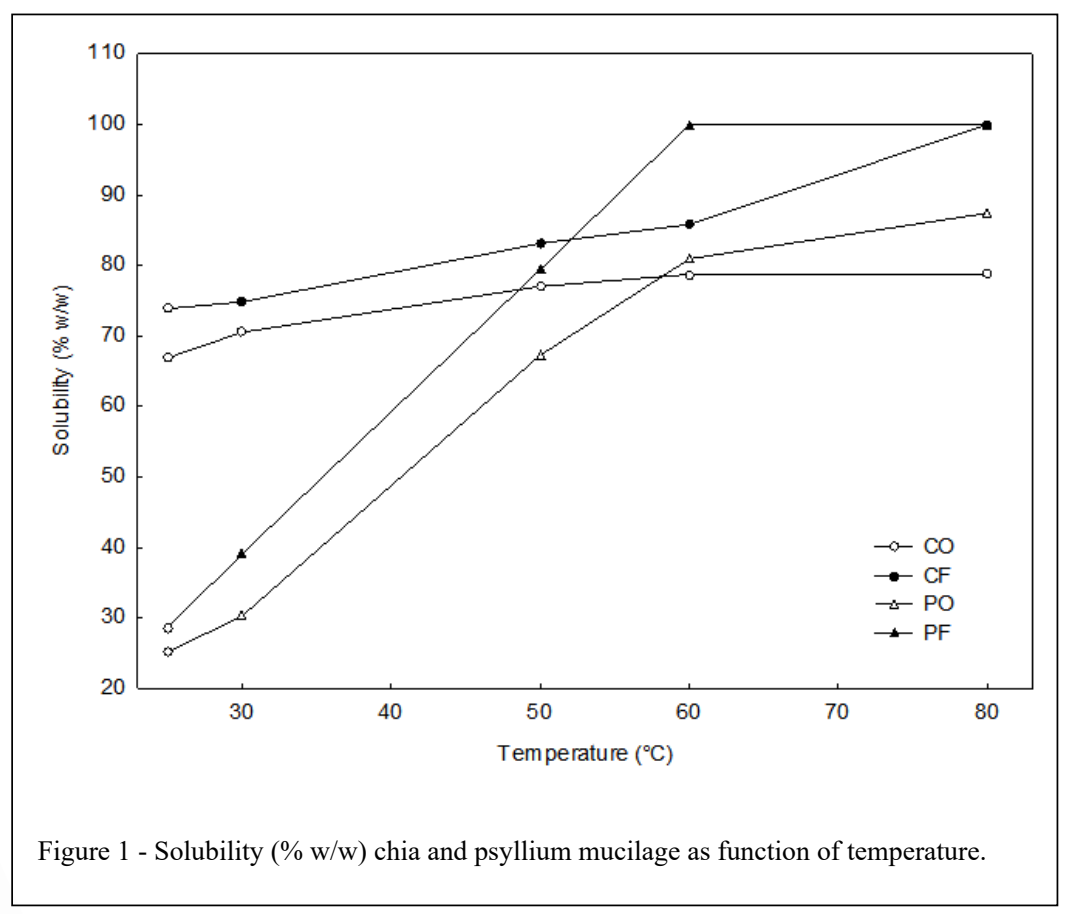

Ciência Rural, v.50, n.8, 2020. 


\section{Rheological properties}

The variation in apparent viscosity as a function of shear rate at $25{ }^{\circ} \mathrm{C}$ is shown in figure 2. The viscosity of all samples decreased as the shear rate increased, thus revealing the pseudo plastic behavior of mucilage. At first, the mucilage molecules are disorganized and only partially aligned, which makes the viscosity higher. As the rate of deformation increases, the molecules become aligned and oriented, thereby reducing internal friction and viscosity (KOOCHEKI et al., 2013; CAPITANI et al., 2013b).

At low shear rate, the freeze dried chia mucilage sample showed the highest apparent viscosity when compared to oven dried chia. This difference may be related to the drying temperature, causing an impact on the molecular weight of the polysaccharide which may in turn affect the viscosity of the gum dispersions. In general, the drying process can provide a broad range of molecular weight depending on the type and condition of drying, thus varying viscosity (NEP \& CONWAY, 2011).
In the case of psyllium husk mucilage, the effect was inverse, the oven dried sample had higher initial apparent viscosity than the freeze dried. Different viscosities of samples could be also explained by the chemical structure, i.e., protein content. PF showed higher protein content (Table 1) than $\mathrm{PO}$ samples; and consequently, apparent viscosity of PF was lower than PO. Similar results were observed by Youssef et al. (2009) and Amid \& Mirhosseini (2012). Youssef et al. (2009) showed that high viscosity was related to high molecular weight, and the molecular weight of Fenugreek gum increased by removing the attached protein, thereby increasing viscosity.

The mucilage rheological data was fitted to mathematical models and the results are shown in table 3. Comparing the sum of errors and the $\mathrm{R}^{2}$ of the models, it can be observed that the Power law and Herschel-Bulkley model were the best to describe the viscous flow behavior of the mucilage of chia seeds (Figure 3) throughout the experiment. These models are very similar, the latter being more comprehensive than the first, because it considers the existence of a

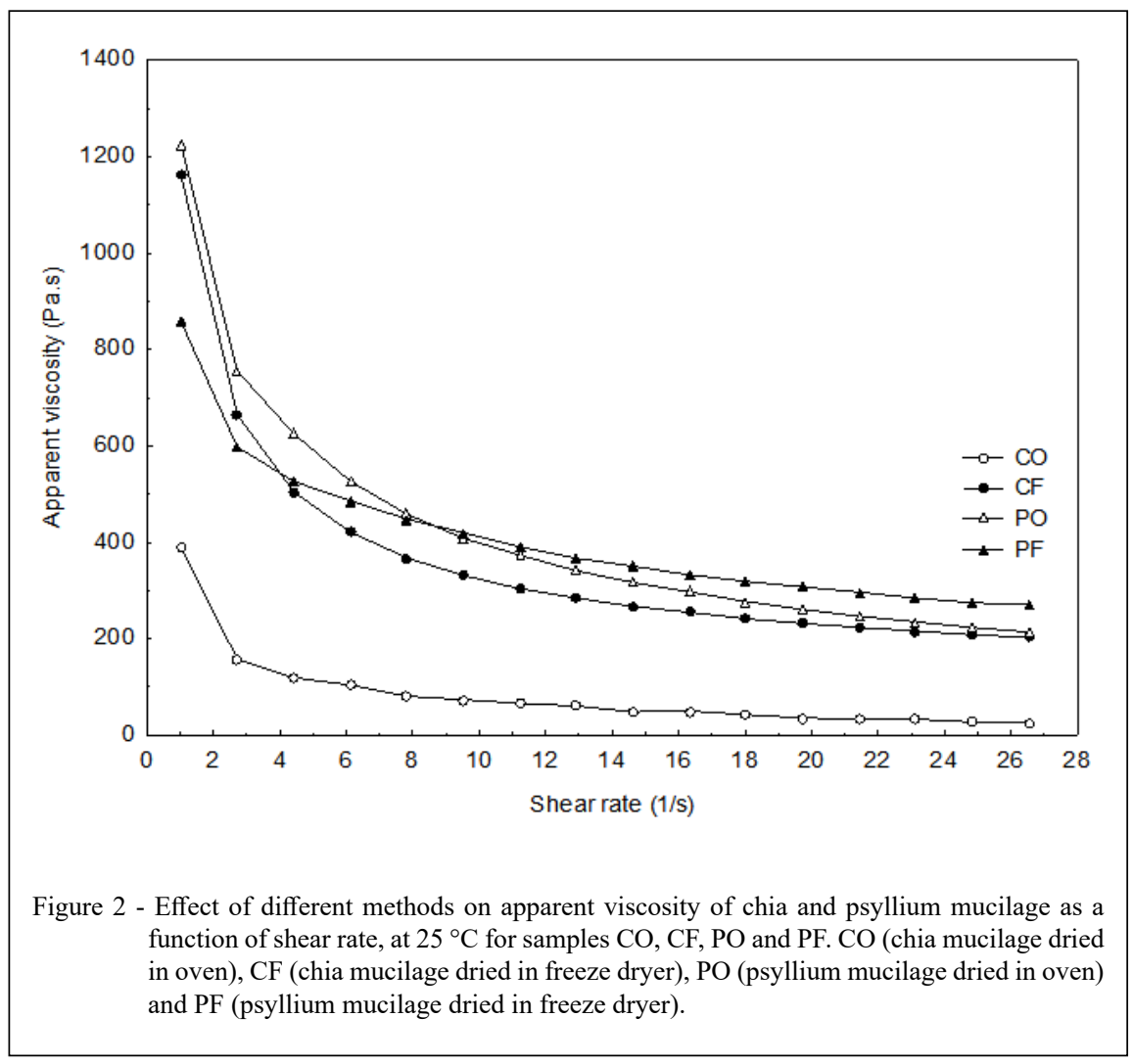

Ciência Rural, v.50, n.8, 2020. 
Table 3 - Parameters of the Power Law, Bingham, Herschel-Bulkley and Casson model for different drying methods.

\begin{tabular}{|c|c|c|c|c|c|c|c|c|c|c|c|c|c|c|c|c|c|}
\hline & \multicolumn{4}{|c|}{----------Power law----------- } & \multicolumn{4}{|c|}{--------Bingham model------- } & \multicolumn{4}{|c|}{---------Casson model--------- } & \multicolumn{5}{|c|}{------Herschel-Bulkley model------ } \\
\hline & $\begin{array}{c}\mathrm{k}_{\mathrm{p}} \\
\left(\mathrm{Pa} \cdot \mathrm{s}^{\mathrm{n}}\right)\end{array}$ & $\mathrm{n}_{\mathrm{p}}$ & $\mathrm{R}^{2}$ & $\mathrm{SE}$ & $\begin{array}{l}\tau_{0 \mathrm{~B}} \\
(\mathrm{~Pa})\end{array}$ & $\begin{array}{c}\eta_{\mathrm{B}} \\
(\mathrm{Pa} . \mathrm{s})\end{array}$ & $\mathrm{R}^{2}$ & $\mathrm{SE}$ & $\begin{array}{c}\tau_{0 \mathrm{C}} \\
(\mathrm{Pa})\end{array}$ & $\begin{array}{c}\eta_{\mathrm{C}} \\
(\mathrm{Pa} . \mathrm{s})\end{array}$ & $\mathrm{R}^{2}$ & $\mathrm{SE}$ & $\begin{array}{r}\tau_{0 \mathrm{H}} \\
(\mathrm{Pa})\end{array}$ & $\begin{array}{c}\mathrm{k}_{\mathrm{H}} \\
\left(\mathrm{Pa} \cdot \mathrm{s}^{\mathrm{n}}\right)\end{array}$ & $\mathrm{n}_{\mathrm{H}}$ & $\mathrm{R}^{2}$ & $\mathrm{SE}$ \\
\hline $\mathrm{CO}$ & 3.73 & 0.26 & 0.990 & 0.330 & 4.74 & 0.18 & 0.908 & 3.224 & 3.47 & 0.23 & 0.967 & 1.197 & 0.26 & 3.50 & 0.28 & 0.990 & 0.329 \\
\hline $\mathrm{CF}$ & 10.61 & 0.49 & 0.998 & 4.432 & 15.297 & 1.53 & 0.978 & 50.352 & 8.12 & 0.88 & 0.996 & 7.691 & 5.03 & 7.09 & 0.58 & 0.999 & 0.627 \\
\hline $\mathrm{PO}$ & 14.83 & 0.41 & 0.992 & 20.065 & 20.58 & 1.54 & 0.911 & 226.033 & 12.28 & 0.82 & 0.961 & 100.595 & 5.14 & 36.75 & 0.24 & 0.989 & 3.350 \\
\hline $\mathrm{PF}$ & 9.90 & 0.60 & 0.997 & 12.987 & 13.99 & 2.33 & 0.967 & 176.99 & 5.43 & 1.19 & 0.987 & 69.994 & 6.68 & 14.32 & 0.51 & 0.990 & 4.911 \\
\hline
\end{tabular}

flow limit. The fit of the Herschel-Bulkley model is shown in figure 3 for chia mucilage.

The initial yield stress and the flow behavior index were higher for the freeze dried samples, probably because the temperature had preserved the structures that give mucilage viscosity.

Consistency index $(\mathrm{k})$ is indicative of the viscous nature and is related to fluid consistency and its resistance to flow (FALGUERA \& IBARZ, 2014; CAPITANI et al., 2015). In this study, the sample of freeze dried chia presented a higher value of $\mathrm{k}$ than the oven dried sample, due to the fact that the drying temperature of the oven could cause partial hydrolysis of the polysaccharides present in chia mucilage, thus generating smaller molecules of the original polymer. Similar result was observed by LEÓN-MARTÍNEZ et al. (2011) when obtaining dried Opuntia ficusindica mucilage by freeze drying and spray drying.

In relation to psyllium mucilage, Power law model was the best to describe the viscous flow behavior (Table 3 ), and the fit of the model is shown in figure 4 . The PF also showed higher flow

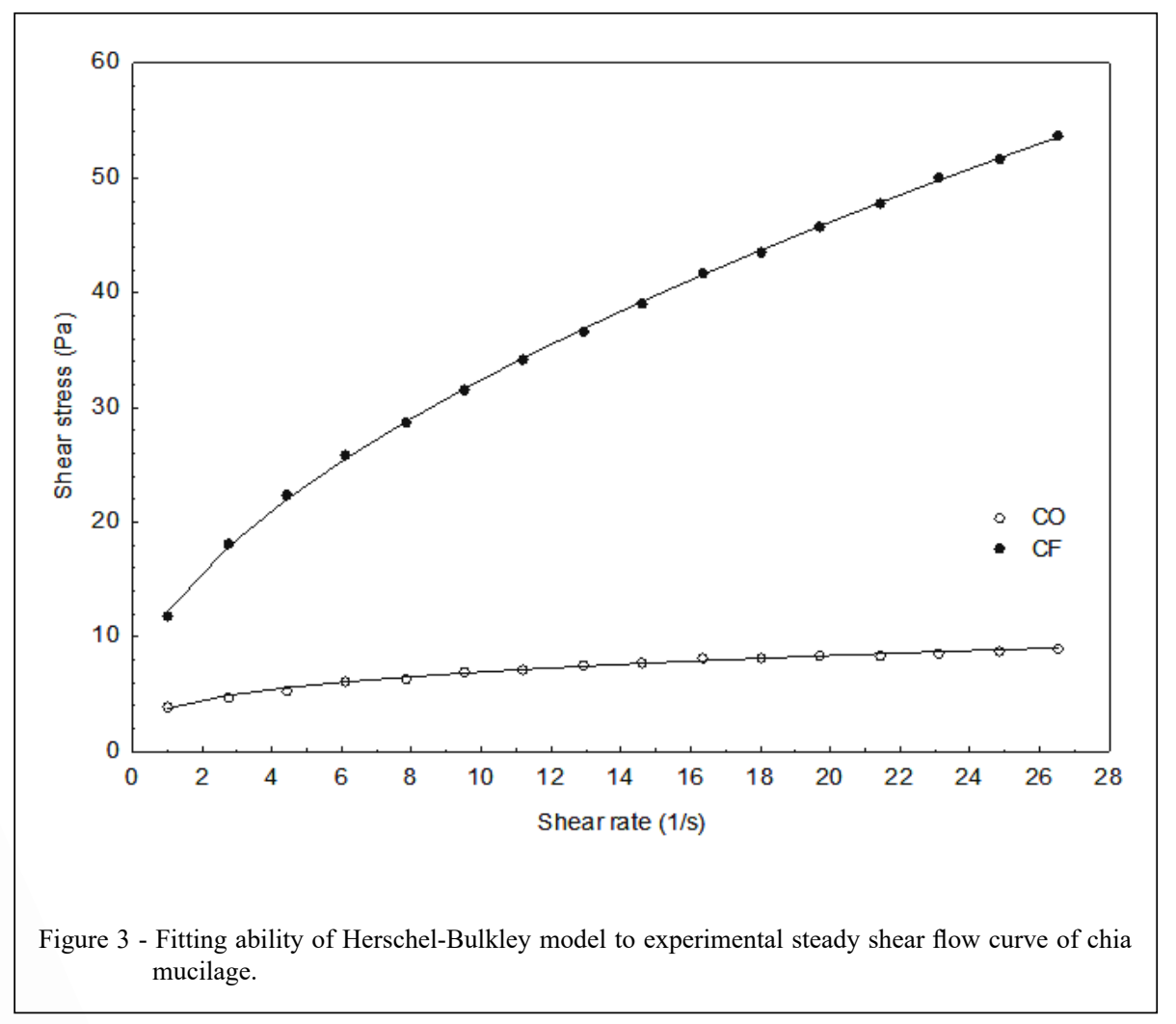

Ciência Rural, v.50, n.8, 2020. 


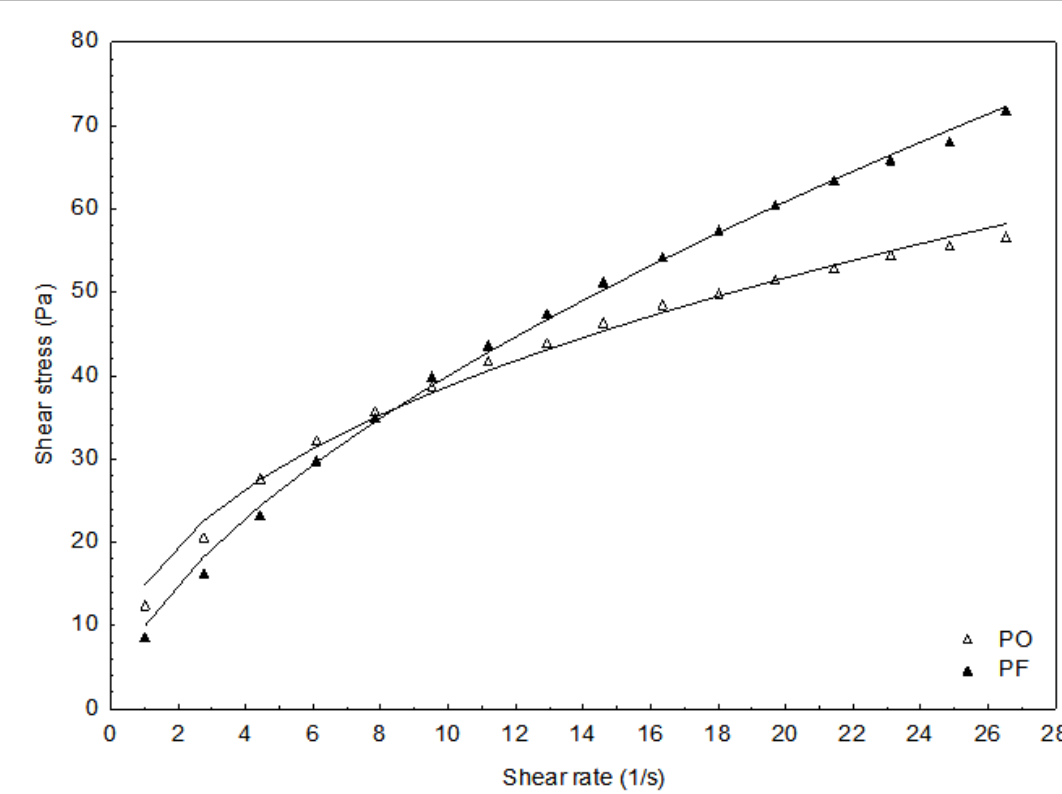

Figure 4 - Fitting ability of Power Law model to experimental steady shear flow curve of psyllium mucilage.

behavior index than PO, although the consistency index was lower for PF. A possible explanation for this comportment is that the drying temperature of the oven may have caused a rearrangement in molecular structure of polysaccharide in such a way that it contributed to increased viscosity; consequently, decreasing consistency index. However, further studies must be performed to prove this hypothesis.

\section{CONCLUSION}

The present research concluded that drying methods influence characteristics of mucilage obtained from chia seed and psyllium husk. Freeze dried samples presented higher results for emulsifying activity, emulsion stability and solubility when compared to oven dried samples. Both mucilage showed pseudo plastic characteristics, with the Herschel-Bulkley and Power law model being the most adequate to describe the flow behavior of the chia and psyllium mucilage, respectively, throughout the experiment.

Conversely, the oven drying method also produced mucilage with the appropriate rheological characteristics and functional properties as compared to freeze drying. Although, the oven drying method changes the characteristics of chia and psyllium mucilage, results are still promising, since it is a low cost method when compared to freeze drying, and the mucilage still presents stabilizer and emulsifying ability for food matrices.

\section{ACKNOWLEDGEMENTS}

The authors acknowledge the financial support from Coordenação de Aperfeiçoamento de Pessoal de Nível Superior (CAPES) scholarship, Fundação Araucária and Conselho Nacional de Desenvolvimento Científico e Tecnológico (CNPQ) (scholarship).

\section{DECLARATION OF CONFLICT OF INTERESTS}

The authors declare no conflict of interest. The founding sponsors had no role in the design of the study; in the collection, analyses, or interpretation of data; in the writing of the manuscript, and in the decision to publish the results.

\section{AUTHORS' CONTRIBUTIONS}

All the authors contributed equally to the manuscript.

\section{REFERENCES}

AL-ASSAF, S. et al. Molecular weight, tertiary structure, water binding and colon behavior of ispaghula husk fiber. Proceedings 
of the Nutrition Society, v.62, n.1, p.211-216, 2003. Available from: <https://doi.org/10.1079/PNS2002216>. Accessed: Oct. 10, 2018. doi: 10.1079/PNS2002216.

ALFREDO, V. et al. Physicochemical properties of a fibrous fraction from chia (Salvia hispanica L.). LWT-Food Science and Technology, v.42, n.1, p.168-173, 2009. Available from: <https:// doi.org/10.1016/j.1wt.2008.05.012>. Accessed: Oct. 11, 2018. doi: 10.1016/j.lwt.2008.05.012.

AMID, B. T; MIRHOSSEINI, H. Effect of different purification techniques on the characteristics of heteropolysaccharide-protein biopolymer from durian (Durio zibethinus) seed. Molecules, v.17, n.9, p.10875-10892, 2012. Available from: <https://doi. org/10.3390/molecules 170910875>. Accessed: Oct. 10, 2002. doi: 10.3390/molecules 170910875

Association of Analytical Chemists (AOAC). (2000). Official method of analysis (17th Ed). Washington, DC: Association of Analytical Chemists.

BETANCUR-ANCONA, D.; et al.,Comparison of the chemical composition and functional properties of Phaseolus lunatus prime and tailing starches. Food Chemistry, v.82, n.2, p. 217-225, 2003. Available from: <https://doi.org/10.1016/S0308-8146(02)00515-0>. Accessed: Oct. 10, 2002. doi: 10.1016/S0308-8146(02)00515-0.

BUSHWAY, A. A.; BELYEA, P. R.; BUSHWAY, R. J. Chia seed as a source of oil, polysaccharide, and protein. Journal of Food Science, v.46, n.5, p.1349-1350, 1981. Available from: <https:// onlinelibrary.wiley.com/doi/abs/10.1111/j.1365-2621.1981. tb04171.x>. Accessed: Oct. 10, 2002.

CAMPOS, B. E. et al. Optimization of the mucilage extraction process from chia seeds and application in ice cream as a stabilizer and emulsifier. LWT-Food Science and Technology, v.65, p.874-883, 2016. Available from: <https://doi.org/10.1016/j. lwt.2015.09.021>. Accessed: Oct. 10, 2002. doi: 10.1016/j. lwt.2015.09.021.

CAPITANI, M. I. et al. Rheological properties of aqueous dispersions of chia (Salvia hispanica L.) mucilage. Journal of food engineering, v.149, p.70-77, 2015. Available from: $<$ https://doi. org/10.1016/j.jfoodeng.2014.09.043>. Accessed: Oct. 10, 2002. doi: $10.1016 /$ j.jfoodeng.2014.09.043.

CAPITANI, M. I. et al. Microstructure, chemical composition and mucilage exudation of chia (Salvia hispanica L.) nutlets from Argentina. Journal of the Science of Food and Agriculture, v.93, n.15, p.3856-3862, 2013a. Available from: <https://doi. org/ 10.1002/jsfa.6327>. Accessed: Oct. 10, 2002. doi: 10.1002/ jsfa.6327.

CAPITANI, M. I.; NOLASCO, S. M.; TOMÁS, M. C. Effect of mucilage extraction on the functional properties of Chia meals. In: Food Industry. IntechOpen, 2013b. Available from: $<$ https://doi. org/10.5772/53171>. Accessed: Oct. 10, 2002. doi: 10.5772/53171.

CHAU, C.; CHEUNG, P. C. K.; WONG, Y. Functional properties of protein concentrates from three Chinese indigenous legume seeds. Journal of Agricultural and Food Chemistry, v.45, n.7 p.2500-2503, 1997. Available from: <https://doi.org/10.1021/ jf970047c $>$. Accessed: Oct. 10, 2002. doi: 10.1021/jf970047c.

DICKINSON, E. Hydrocolloids at interfaces and the influence on the properties of dispersed systems. Food hydrocolloids, v.17, n.1, p.25-39, 2003. Available from: <https://doi.org/10.1016/S0268005X(01)00120-5>. Accessed: Oct. 10, 2002. doi: 10.1016/S0268005X(01)00120-5.

FABRE, J. et al. Ultrasonication as a highly efficient method of flaxseed mucilage extraction. Industrial Crops and Products, v.65, p.354-360, 2015. Available from: $<$ https://doi.org/10.1016/j. indcrop.2014.11.015>. Accessed: Oct. 10, 2002. doi: 10.1016/j. indcrop.2014.11.015.

FALGUERA, V.; IBARZ, A. Juice processing: quality, safety and value-added opportunities. CRC Press, 2014.

FERNANDES, S. S; DE LAS MERCEDES SALAS-MELLADO, M. Addition of chia seed mucilage for reduction of fat content in bread and cakes. Food chemistry, v.227, p.237-244, 2017. Available from: $<$ https://doi.org/10.1016/j.foodchem.2017.01.075>. Accessed: Oct. 10, 2002. doi: 10.1016/j.foodchem.2017.01.075.

GUO, Q. et al. Fractionation and physicochemical characterization of psyllium gum. Carbohydrate Polymers, v.73, n.1, p.35-43, 2008. Available from: <https://doi.org/10.1016/j. carbpol.2007.11.001>. Accessed: Oct. 10, 2002. doi: 10.1016/j. carbpol.2007.11.001.

GUO, Q. et al. Microstructure and rheological properties of psyllium polysaccharide gel. Food Hydrocolloids, v.23, n.6, p.1542-1547, 2009. Available from: <https://doi.org/10.1016/j. foodhyd.2008.10.012>. Accessed: Oct. 10, 2002. doi: 10.1016/j. foodhyd.2008.10.012.

KOOCHEKI, A.; TAHERIAN, A. R; BOSTAN, A. Studies on the steady shear flow behavior and functional properties of Lepidium perfoliatum seed gum. Food Research International, v.50, n.1, p.446-456, 2013. Available from: <https://doi.org/10.1016/j. foodres.2011.05.002>. Accessed: Oct. 10, 2002. doi: 10.1016/j. foodres.2011.05.002.

KRYSTYJAN, M. et al. Preparation and characteristics of mechanical and functional properties of starch/Plantago psyllium seeds mucilage films. Starch Stärke, v.69, n.11-12, p.1700014, 2017. Available from: <https://doi.org/10.1002/star.201700014>. Accessed: Oct. 10, 2002. doi: 10.1002/star.201700014.

LEÓN-MARTÍNEZ, F. M. et al. Effects of drying conditions on the rheological properties of reconstituted mucilage solutions (Opuntia ficus-indica). Carbohydrate Polymers, v.84, n.1, p.439-445, 2011. Available from: <https://doi.org/10.1016/j.carbpol.2010.12.004>. Accessed: Oct. 10, 2002. doi: 10.1016/j.carbpol.2010.12.004.

LI, G.; CHANG, K. C. Viscosity and gelling characteristics of sunflower pectin as affected by chemical and physical factors. Journal of agricultural and food chemistry, v.45, n.12, p.47854789, 1997. Available from: <https://doi.org/10.1021/jf9708150>. Accessed: Oct. 10, 2002. doi: 10.1021/jf9708150.

MARTÍNEZ-CRUZ, O.; PAREDES-LÓPEZ, O. Phytochemical profile and nutraceutical potential of chia seeds (Salvia hispanica L.) by ultra high performance liquid chromatography. Journal of Chromatography A, v.1346, p.43-48, 2014. Available from: $<$ https://doi.org/10.1016/j.chroma.2014.04.007>. Accessed: Oct. 10, 2002. doi: 10.1016/j.chroma.2014.04.007.

MIRHOSSEINI, H.; AMID, B. T.; CHEONG, K. W. Effect of different drying methods on chemical and molecular structure of heteropolysaccharide-protein gum from durian seed. Food 
Hydrocolloids, v.31, n.2, p.210-219, 2013. Available from: $<$ https://doi.org/10.1016/j.foodhyd.2012.11.005>. Accessed: Oct. 10, 2002. doi: 10.1016/j.foodhyd.2012.11.005.

MIRHOSSEINI, H.; AMID, B. T. A review study on chemical composition and molecular structure of newly plant gum exudates and seed gums. Food Research International, v.46, n.1, p.387-398, 2012. Available from: $<$ https://doi.org/10.1016/j. foodres.2011.11.017>. Accessed: Oct. 10, 2002. doi: 10.1016/j. foodres.2011.11.017.

NAWAR, W. W. Chemical changes in lipids produced by thermal processing. 1984. Available from: <https://doi.org/10.1021/ ed061p299>. Accessed: Oct. 10, 2002. doi: 10.1021/ed061p299.

NEP, E. I.; CONWAY, B. R. Physicochemical characterization of grewia polysaccharide gum: Effect of drying method. Carbohydrate Polymers, v.84, n.1, p.446-453, 2011. Available from: <https://pubs. acs.org/doi/pdf/10.1021/ed061p299>. Accessed: Oct. 10, 2002.

PROSKY, L. et al. Determination of insoluble, soluble, and total dietary fiber in foods and food products: interlaboratory study. JournalAssociation of Official Analytical Chemists, v.71, n.5, p.1017-1023, 1988. Available from: <https://doi.org/10.1093/jaoac/71.5.1017>. Accessed: Oct. 10, 2002. doi: 10.1093/jaoac/71.5.1017.

RAYMUNDO, A.; FRADINHO, P.; NUNES, M. C. Effect of Psyllium fiber content on the textural and rheological characteristics of biscuit and biscuit dough. Bioactive carbohydrates and dietary fiber, v.3, n.2, p.96-105, 2014. Available from: <https:// doi.org/10.1016/j.bcdf.2014.03.001>. Accessed: Oct. 10, 2002. doi: 10.1016/j.bcdf.2014.03.001.

RUDKOWSKA, I. Lipid lowering with dietary supplements: focus on diabetes. Maturitas, v.72, n.2, p.113-116, 2012. Available from:
$<$ https://doi.org/10.1016/j.maturitas.2012.03.001>. Accessed: Oct. 10, 2002. doi: 10.1016/j.maturitas.2012.03.001.

SALEHI, F.; KASHANINEJAD, M. Effect of different drying methods on rheological and textural properties of Balangu seed gum. Drying Technology, v.32, n.6, p.720-727, 201. Available from: $<$ https://doi.org/10.1080/07373937.2013.858264>. Accessed: Oct. 10, 2002. doi: 10.1080/07373937.2013.858264.

SCIARINI, L. S. et al. Chemical composition and functional properties of Gleditsia triacanthos gum. Food Hydrocolloids, v.23, n.2, p.306-313, 2009. Available from: <https://doi.org/10.1016/j. foodhyd.2008.02.011>. Accessed: Oct. 10, 2002 doi: 10.1016/j. foodhyd.2008.02.011.

TIMILSENA, Y. P. et al. Preparation and characterization of chia seed protein isolate-chia seed gum complex coacervates. Food hydrocolloids, v.52, p.554-563, 2016. Available from: <https:// doi.org/10.1016/j.foodhyd.2015.07.033>. Accessed: Oct. 10, 2002. doi: 10.1016/j.foodhyd.2015.07.033.

WANG, Y. et al. Effects of drying methods on the functional properties of flaxseed gum powders. Carbohydrate Polymers, v.81, n.1, p.128-133, 2010. Available from: <https://doi org/10.1016/j.carbpol.2010.02.005>. Accessed: Oct. 10, 2002. doi: 10.1016/j.carbpol.2010.02.005.

YOUSSEF, M. K. et al. Purification and partial physicochemical characteristics of protein free fenugreek gums. Food Hydrocolloids, v.23, n.8, p.2049-2053, 2009. Available from: $<$ https://doi.org/10.1016/j.foodhyd.2009.03.017>. Accessed: Oct. 10, 2002. doi: 10.1016/j.foodhyd.2009.03.017.

YU, L. et al. U. S. Patent No. 6,248,373. Washington, DC: U.S. Patent and Trademark Office, 2001. 